\title{
TOWARDS A STRATEGY FOR THE INTRODUCTION OF INFORMATION AND COMPUTER LITERACY (ICL) COURSES
}

\author{
Tueerd Plomp and Gerrit Carleer \\ Twente University of Technology, Department of Education. Division of Curriculum Technology, \\ P.O. Box 217, 7500 AE Enschede, The Netherlands
}

(Received 19 June 1986; accepted 21 July 1986)

\begin{abstract}
An important goal of the national policy on computers in education in the Netherlands is the familiarization of all citizens with information technology. This policy was a plea for some basic education in information and computer literacy. In the beginning of the implementation of this basic education for all a national survey (about grassroots developments) in Dutch junior secondary education was executed (Spring. 1984) with the following objectives: (i) to collect information which can serve as a baseline for the evaluation of future developments and (ii) to perform a context analysis to provide policy makers. innovation planners and curriculum developers with information about the state-of-the-art on information and computer literacy in the schools. The survey instruments were partly developed with as underlying structure some of the factors which are influencing the implementation of educational changes. The instruments were submitted to a sample of 462 schools representing the different types of junior secondary schools. Variation between the schools was obtained by distinguishing different levels of involvements of schools in information and computer literacy. This paper analyses how far in the schools, which ara experimenting with information and computer literacy on their own initiative. some of the implementation factors of Fullan are fulfilled. Based upon this analysis a recommendation for a policy strategy for introducing this new domain in the schools is formulated.
\end{abstract}

\section{INTRODUCTION AND OBJECTIVES}

Since the early eighties the introduction of new information technology in education has been intensively discussed in the Netherlands. This discussion was stimulated by two white papers published by the government (in 1982 and 1984) and by advisory reports of different groups and committees. In his 1982 white paper, the Dutch Minister of Education and Sciences stated as an important goal for national policy the familiarization of all citizens with information technology. This was, in fact, a plea for some basic education; not aimed at computer literacy in the meaning of learning programming skills and how to operate a computer, but an introduction to "information and computer science" conceived of as that part of computer science and information science that every citizen should know. This basic education should be part of the curriculum of the lower secondary education.

This new domain is called "information and computer literacy" (ICL) [1]. Parallel to the national discussions many grassroot developments took place: many secondary schools were in some way or another busy with the introduction of the computer in their education.

The introduction of ICL as a new domain (either as a separate course or not) in Dutch secondary schools will have consequences for the curriculum, classroom organization, teachers' roles, etc. and can therefore be conceived as an innovation of a considerable size. For implementing successfully a national policy on computers in education, it is relevant to know what schools are already doing in this domain and which factors are influencing their choices and activities.

As a first step we decided, in Fall 1982, to assess the situation in Dutch junior secondary education with respect to this innovation. The objectives for this national survey study were: (i) to collect information which can serve as a baseline for the evaluation of future developments and (ii) to perform a context or situation analysis to provide policy makers, innovation planners and curriculum developers with information about ICL state-of-the-art in the schools. The results are reported in Valkenburg and Carleer [2].

The objective of this study is to analyze the survey data starting from the question: what can be learned from grassroots developments with respect to ICL in Dutch secondary schools (i.e. from "spontaneous" change) to optimally prepare a planned change in schools. 
During the data collection for the survey study, much background information became available about the character of the innovation, the schools and the teachers: these will be summarized. We will further investigate how far the implementation factors identified by Fullan [3] are also consistent with this innovation. Our conclusion will be presented as a working hypothesis for a recommendation for a strategy for introducing ICL in schools.

\section{THEORETICAL FRAMEWORK}

Fullan $[3,4]$ discusses factors which are supported to influence the implementation of innovations. Change in practice occurs when certain elements occur in combination: attention to the development of clear and validated materials; active administrative support and leadership especially at school level; focused, ongoing inservice or staff development activities: the development of collegiality and other interaction-based conditions at the school level; and the selective use of external resources (both people and materials) [4, p. 1214]. Although the governmental white papers do not refer to particular strategies for introducing ICL in schools and the survey study was directed at getting an overview of spontaneous developments at the school level, the instruments used in the survey study are (partly) developed based on some of the factors put forward by Fullan. This implies that in this study no causal relationships between implementation strategies and the degree of implementation of ICL in Dutch schools could be investigated. But by studying the relationship between the degree of implementation of ICL in Dutch schools and the implementation factors some empirical contribution to Fullan's theory can be given. Further, by using the implementation factors as an underlying framework for measuring how far ICL is already implemented in Dutch schools (independently of national policy measures) recommendations can be formulated for more particular strategies on a national and on school level.

To obtain variation between schools with respect to this innovation it was nccessary to categorize the schools according to degrees of implementation. The following levels have been established:

(1) Schools which are not active.

(2) Schools which are in an orientation phase, i.e. at least one teacher is orienting himself to the innovation (e.g. by attending an in-service course).

(3) Schools which are teaching ICL to students (active on student level).

So, the main question to be investigated is whether there is a relationship between some of the factors mentioned by Fullan and the actual degrees of implementation.

\section{RESEARCH DESIGN}

\section{Sample and instruments}

For the survey study a stratified sample of 471 schools was drawn out of the population of 2378 Dutch (junior) secondary schools, following a multi-stage sampling plan. The sample was stratified according to the different types of secondary schools: (a) general secondary education (GSE), (b) lower vocational education (LVE), (c) combinations of (a) and (b): GSE/LVE and (d) middle schools (a small group of 17 experimental comprehensive schools). Three hundred and seven schools of the first sample were willing to participate in the study. In the sample. the nonrespondents were replaced by corresponding schools from a second sample and in the next stage of the sampling from a third sample. After these three rounds the sample consisted of 462 schools, stratified as follows: 202 GSE schools, 187 LVE schools, 56 GSE/LVE schools, 17 middle schools.

A number of instruments was developed for the survey to measure the degree of implementation of ICL and some of Fullan's factors. Drafts of the instruments were developed by the researchers and a panel of experts. They were pilot tested in a few schools.

The instruments are a general school questionnaire (38 questions) and an ICL-questionnaire covering aspects of introducing this new topic in the school curriculum, including the degree of implementation. 


\section{Non-response analysis}

For the interpretation and the generalizability of the results it is important to know how the non-respondents differ from the schools in the sample. In the survey, non-response could occur at two times.

The first time non-response occurred was during the sampling procedue. From the 471 schools in the first sample 307 schools were willing to participate in the study. One hundred and three schools refused to participate, while 61 schools did not respond at all, not even after an extra reminder. A first analysis of the responses of the 103 schools who were not willing to participate (but who answered the question about whether the school was already active with ICL or not) gave rise to the suspicion that schools which were not active with ICL were not willing to take part in the study. The level of involvement in ICL of the non-respondents was obtained by a telephone inquiry. A complete picture of the first sample of 471 schools, which were approached to participate in the study, can be seen in Table 1.

\begin{tabular}{|c|c|c|c|c|}
\hline \multirow[b]{2}{*}{ Level of involvement in ICL } & \multicolumn{2}{|c|}{$\begin{array}{l}\text { Willing to participate } \\
\text { in the study }\end{array}$} & \multicolumn{2}{|c|}{$\begin{array}{l}\text { Not willing to participate } \\
\text { in the study }\end{array}$} \\
\hline & ABS & $\%$ & ABS & $\%$ \\
\hline Schools not active with ICL & 54 & 17.6 & 76 & 47.2 \\
\hline $\begin{array}{l}\text { Schools active with ICL } \\
\text { (orientation or on student level) }\end{array}$ & 253 & 82.4 & 85 & 52.8 \\
\hline Total $468^{*}$ & 307 & 100.0 & 161 & 100.0 \\
\hline
\end{tabular}

From this table, it is clear that the schools which are (not) yet involved in the introduction of ICL could be underrepresented in the sample in comparison to the schools who were willing to contribute to the study.

A second moment of non-response happened during the data collection phase. Of the 462 schools in the sample, after reviewing the data it appeared that 80 schools could not be used in the data analysis, which means that the ultimate sample consisted of 382 schools. However, the second non-response did not influence the distribution of the schools over the variable "involvement in ICL" (see Table 2). So in the ultimate sample the schools not (yet) active with ICL are underrepresented.

Table 2. Actual and expected distribution of schools in the sample (absolute and percentages)

\begin{tabular}{|c|c|c|c|c|c|c|}
\hline \multirow[b]{2}{*}{ Level of involvement in ICL. } & \multicolumn{2}{|c|}{$\begin{array}{l}\text { Expected distribution } \\
\text { when all schools } \\
\text { should have returned } \\
\text { questionnaires }\end{array}$} & \multicolumn{2}{|c|}{$\begin{array}{l}\text { Actual distribution } \\
\text { of schools who } \\
\text { returned questionnaires }\end{array}$} & \multicolumn{2}{|c|}{$\begin{array}{l}\text { Non-response } \\
\text { distribution }\end{array}$} \\
\hline & ABS & $\%$ & ABS & $\%$ & ABS & $\%$ \\
\hline Schools not active with ICL & 84 & 18.2 & 70 & 18.3 & 14 & 17.5 \\
\hline $\begin{array}{l}\text { Schools active with ICL } \\
\text { (orientation or on student level) }\end{array}$ & 378 & 81.8 & 312 & 81.7 & 66 & 82.5 \\
\hline Total & 462 & 100.0 & 382 & 100.0 & 80 & 100.0 \\
\hline
\end{tabular}

\section{Date source}

The ultimate sample consisted of 462 schools, of which $81.8 \%$ were in some way or another active with introducing ICL in their education (see Table 2).

The data collection took place in April 1984. The response percentage was $83 \%$, i.e. 382 schools completed both questionnaires. Analysis of the data shows that the sample has a good distribution over the strata, while the questionnaires were answered very completely.

\section{RESULTS}

From Table 2 it can be concluded that 70 schools $(18.3 \%)$ in the ultimate sample of 382 schools were not active at all with ICL. Of the remaining schools ICL is being taught to their pupils in 107 schools $(28 \%)$, while the other 205 schools $(53.7 \%)$ were in an orientation phase. 
Intolvement in decision making about adoption and implementation of ICL

Teachers were playing the most important role in decisions about adoption and implementation of ICL. Their role is much more important than that of the principal or school administrators, while the proper authorities and parents have had hardly any influence on this process (see Tables 3 and 4).

From Table 3 we see that teachers in both subsamples were the main group in originating adoption decisions. In schools which were still in an orientation phase in Spring 1984, the school administration was playing a relatively more important role in the adoption process than in schools which were further along in the implementation process.

\begin{tabular}{|c|c|c|c|c|}
\hline \multirow[b]{2}{*}{ Originators } & \multicolumn{2}{|c|}{$\begin{array}{c}\text { Schools active on } \\
\text { student level }(N=107)\end{array}$} & \multicolumn{2}{|c|}{$\begin{array}{l}\text { Schools in orientation } \\
\text { phase }(N=203)\end{array}$} \\
\hline & ABS & $\%$ & ABS & $\%$ \\
\hline Teachers & 78 & 72.9 & 147 & 72.4 \\
\hline Administrators & 51 & 47.7 & 120 & 59.1 \\
\hline Parents & 5 & 4.7 & 4 & 2.0 \\
\hline Authorities & 12 & 11.2 & 17 & 8.4 \\
\hline Students & 1 & 0.9 & 3 & 1.5 \\
\hline
\end{tabular}

In schools which are teaching ICL to their students, the teachers of the new topic are the most important decision makers (see Table 4). In those schools a team of three teachers is responsible for the new course, of which one is also a member of the school administration in most cases. In schools which are in the orientation phase, the picture is slightly different (Table 4). The (future) ICL teachers are in an orientation phase (e.g. inservice training) and in most cases decisions about the introduction of ICL as a course for students were not yet taken. In these schools the group of all teachers and the proper authorities play a more important role in decision making, next to the ICL teachers and the school administration.

Table 4. Groups involved in decision making about (the introduction of) ICL (absolute and percentages)

\begin{tabular}{|c|c|c|c|c|}
\hline \multirow[b]{2}{*}{ Group } & \multicolumn{2}{|c|}{$\begin{array}{c}\text { Schools active on } \\
\text { student level }(N=106)\end{array}$} & \multicolumn{2}{|c|}{$\begin{array}{l}\text { Schools in orientation } \\
\text { phase }(N=203)\end{array}$} \\
\hline & ABS & $\%$ & ABS & $\%$ \\
\hline All teachers & 8 & 7.5 & 44 & 21.7 \\
\hline Teachers of ICL & 96 & 90.6 & 123 & 60.6 \\
\hline Administrators & 73 & 68.9 & 141 & 69.5 \\
\hline Parents & 5 & 4.7 & 7 & 3.4 \\
\hline Authorities & 15 & 14.2 & 41 & 20.2 \\
\hline
\end{tabular}

Reasons for not being active with ICL

The 70 schools in the sample who were not active with ICL in Spring 1984 were asked to indicate their reasons for this inactivity. The answers of the 69 schools who returned the questionnaire are summarized in Table 5 .

Table 5. Reasons for not being active with $\mathrm{ICL}(N=69$, absolute and percentages)

\begin{tabular}{|c|c|c|c|c|c|c|c|c|}
\hline \multirow[b]{2}{*}{ Reasons for not being active } & \multicolumn{2}{|c|}{$\begin{array}{c}\text { Not playing } \\
\text { any role }\end{array}$} & \multicolumn{2}{|c|}{$\begin{array}{c}\text { Little } \\
\text { importance }\end{array}$} & \multicolumn{2}{|c|}{ Neutral } & \multicolumn{2}{|c|}{$\begin{array}{c}\text { Very } \\
\text { important }\end{array}$} \\
\hline & ABS & $\%$ & ABS & $\%$ & ABS & $\%$ & $A B S$ & $\%$ \\
\hline No task of the school & 37 & 53.6 & 25 & 36.2 & 5 & 7.2 & 2 & 2.9 \\
\hline Government gives too little facilities & 14 & 20.3 & 8 & 11.6 & 8 & 11.6 & 39 & 56.5 \\
\hline Shortage of external expert support & 15 & 21.7 & 12 & 17.4 & 14 & 20.3 & 28 & 40.6 \\
\hline No space on timetable & 14 & 20.3 & 23 & 33.3 & 8 & 11.6 & 24 & 34.8 \\
\hline No expertise in school & 7 & 10.1 & 15 & 21.7 & 13 & 18.8 & 34 & 49.3 \\
\hline No hardware in school & 7 & 10.1 & 7 & 10.1 & 2 & 2.9 & 53 & 76.8 \\
\hline Teachers have too little time & 16 & 23.2 & 15 & 21.7 & 9 & 13.0 & 29 & 42.0 \\
\hline No enthusiasm among teachers & 23 & 33.3 & 25 & 36.2 & 14 & 20.3 & 7 & 10.1 \\
\hline ICL is just a fad & 33 & 47.8 & 24 & 34.8 & 7 & 10.1 & 5 & 7.2 \\
\hline Shortage of teaching-learning materials & il & 15.9 & 13 & 18.8 & 5 & 7.2 & $\div 0$ & 58.0 \\
\hline
\end{tabular}


The most important reason at the time of this study is the lack of hardware; 53 of the schools $(76.8 \%)$ in this group did not have any hardware at that time. This reason will not be a valid one within a few years. While in the total sample of this study $63.3 \%$ of the schools had a computer, a population survey one year later indicated that $74.1 \%$ had at least one computer. The policy of the Dutch government is to provide every junior secondary school with a network of eight micro-computers by the end of 1988. Two other important reasons for inactivity are the lack of facilities provided by the government (referring to the shortage of means for buying hardware and for providing teachers with extra time and other resources to become competent) and the shortage of good teaching-learning materials. It is worthwhile to remark that ICL is hardly considered in these schools as just a fad, to which the schools should not pay any attention. One must conclude that in these schools the combination of factors mentioned by Fullan as conditions for successful implementation of changes are not fulfilled.

\section{Factors influencing a successful introduction of ICL}

Schools who are active with ICL (i.e. either in an orientation phase or teaching it to students) were asked (i) which factors they consider of importance for a successful implementation of ICL in their schools and (ii) which type of objections and problems are put forward in the school (e.g. by teachers or parents) against this innovation. The data are summarized in Tables 6 and 7 .

Table 6. Factors considered by schools as important for a successful introduction of ICL

\begin{tabular}{|c|c|c|c|c|c|c|c|c|}
\hline \multirow[b]{3}{*}{ Factors } & \multicolumn{4}{|c|}{$\begin{array}{c}\text { Mentioned by schools in } \\
\text { orientation phase }(N=202) \text { as }\end{array}$} & \multicolumn{4}{|c|}{$\begin{array}{l}\text { Mentioned by schools active } \\
\text { on student level }(N=107) \text { as }\end{array}$} \\
\hline & \multicolumn{2}{|c|}{$\begin{array}{l}\text { Nothardly } \\
\text { important }\end{array}$} & \multicolumn{2}{|c|}{$\begin{array}{c}\text { Very } \\
\text { important }\end{array}$} & \multicolumn{2}{|c|}{$\begin{array}{l}\text { Not/hardly } \\
\text { important }\end{array}$} & \multicolumn{2}{|c|}{$\begin{array}{c}\text { (Very) } \\
\text { important }\end{array}$} \\
\hline & ABS & $\%$ & ABS & $\%$ & $\mathrm{ABS}$ & $\%$ & ABS & ; \\
\hline Availability of computer room & 38 & 18.8 & 164 & 81.2 & 13 & 12.1 & 94 & 87.9 \\
\hline $\begin{array}{l}\text { Possibility of acquiring equipment } \\
\text { Availability of sufficient }\end{array}$ & 3 & 1.5 & 199 & 98.5 & 10 & 9.3 & 97 & 90.7 \\
\hline teaching-learning materials & 38 & 18.8 & 164 & 81.2 & 25 & 23.4 & 82 & 76.6 \\
\hline Availability of sufficient software & 31 & 15.3 & 171 & 84.7 & 25 & 23.4 & 82 & 76.6 \\
\hline External expert support & 109 & 54.0 & 93 & 46.0 & 62 & 57.9 & 45 & 42.1 \\
\hline $\begin{array}{l}\text { Space on timetable } \\
\text { Expertise in the school on (micro) }\end{array}$ & 36 & 17.8 & 166 & 82.2 & 14 & 13.1 & 93 & 86.9 \\
\hline computers and programming & 42 & 20.1 & 160 & 79.2 & 15 & 14.0 & $9:$ & 86.0 \\
\hline Possibilities of attending inservice courses & 42 & 20.1 & 160 & 79.2 & 32 & 29.9 & 75 & 70.1 \\
\hline
\end{tabular}

Analyzing the results one can conclude from Table 6 that the schools consider successful introduction of ICL highly dependent on material support (e.g. hardware, courseware and teaching-learning materials) and on non-material facilities like inservice training and extra teaching hours. Factors referring to the acquisition of equipment have the highest score. Schools consider this a very important factor. This also becomes apparent from Table 7, as $31.8 \%$ of the schools in the orientation phase mention "no hardware in school" as a problem.

Table 7. Objections and problems with the introduction of ICL put forward in schools active with ICL (absolute and percentage)

\begin{tabular}{|c|c|c|c|c|}
\hline \multirow[b]{2}{*}{ Objections and problems } & \multicolumn{2}{|c|}{$\begin{array}{l}\text { Mentioned by schools } \\
\text { in orientation phase } \\
\qquad(N=204)\end{array}$} & \multicolumn{2}{|c|}{$\begin{array}{l}\text { Mentioned by schools } \\
\text { active on student level } \\
\qquad(N=107)\end{array}$} \\
\hline & ABS & $\%$ & ABS & $\%$ \\
\hline $\begin{array}{l}\text { Government gives too little personnel } \\
\text { and other facilities }\end{array}$ & 122 & 59.8 & 69 & 64.5 \\
\hline Shortage of external expert support & 52 & 25.5 & 15 & 14.0 \\
\hline Shortage of teaching-learning materials & 80 & 39.2 & 40 & 37.4 \\
\hline No space on timetable & 97 & 47.5 & 57 & 53.3 \\
\hline Too little time available & 59 & 28.9 & 44 & 41.1 \\
\hline ICL is just a fashion & 39 & 19.1 & 18 & 16.8 \\
\hline No expertise in school & 30 & 14.7 & 12 & 11.2 \\
\hline No hardware in school & 65 & 31.8 & $1 !$ & 10.3 \\
\hline $\begin{array}{l}\text { Working with computers inhibits creativity } \\
\text { Computers influence employment }\end{array}$ & 9 & 4.4 & 4 & 3.7 \\
\hline $\begin{array}{l}\text { in schools negatively } \\
\text { Working with computers gives no positive }\end{array}$ & 3 & 1.5 & 3 & 2.8 \\
\hline $\begin{array}{l}\text { Working with computers gives no positive } \\
\text { contribution to personal development }\end{array}$ & 12 & 5.9 & 5 & 4.7 \\
\hline No objections mentioned & 41 & 20.1 & 22 & 20.6 \\
\hline
\end{tabular}


In the Netherlands the national government pays for education, i.e. for teacher's salaries as well as for all other costs of education. From Table 6 one can conclude that the support of the government is considered by the schools as crucial for a successful implementation, because many of the factors with a high score should be provided by the government. On the other hand, from Table 7, we can conclude that schools consider the government support as insufficient. Not only has the item "government gives too little personnel and other facilities" the highest score, but other items with a high score in this table can be considered as elaborations of the first one (e.g. no space on time table, too little time available, shortage of teaching-learning materials). It is remarkable in Table 6 that only the factor "availability of external expert support" has a rather low score, while the factor "expertise in the school on (micro)computers and programming" is considered to be an important factor. If one combines this with the result in Table 7 that "no expertise in school" is only experienced in a small number of schools as a problem $(14.7 \%$ resp. $11.2 \%)$, then one can conclude that schools/teachers have the opinion that they know enough by themselves and consider themselves able to acquire relevant knowledge on their own. From other data in the study, we know that the main activities to qualify themselves are attending inservice courses (schools in orientation phase: $41 \%$, schools active on student level: $43 \%$ ) and self study (schools in orientation phase: $25 \%$, schools active on student level even $39 \%$ ).

\section{Knowledge about the innotation}

Information and computer literacy (ICL) as a label for a new domain may mean different things to different people. This can be partly a consequence of not being well informed about the goals and content of ICL, but also because what is being conceived as ICL is still developing [1]. In the Netherlands many sources are available to the schools to get informed about goals and content of ICL, such as publications of the National Foundation of Curriculum Development. inservice courses (of teacher training institutes), journals and periodicals, teachers who have attended inservice courses (also teachers from other schools), documentation from publishers and computer firms.

Schools were asked how far they are acquainted with the goals and the content of the newly defined domain of ICL (see Table 8). From this table we may conclude that the more actively schools are involved in ICL the more they report being acquainted with the goals and the content

\begin{tabular}{|c|c|c|c|c|c|c|}
\hline \multirow{2}{*}{$\begin{array}{l}\text { Acyuainted } \\
\text { with ICL }\end{array}$} & \multicolumn{2}{|c|}{$\begin{array}{l}\text { Schools active on } \\
\text { student level } \\
(N=106)\end{array}$} & \multicolumn{2}{|c|}{$\begin{array}{l}\text { Schools in } \\
\text { orientation phase } \\
(N=202)\end{array}$} & \multicolumn{2}{|c|}{$\begin{array}{l}\text { Schools not active } \\
\qquad(N=70)\end{array}$} \\
\hline & $A B S$ & $\%$ & ABS & $\%$ & ABS & $\%$ \\
\hline Not & 4 & 3.8 & 14 & 6.9 & 16 & 22.9 \\
\hline A little & 11 & 10.4 & 51 & 25.2 & 18 & 25.7 \\
\hline Moderately & 30 & 28.3 & 48 & 23.8 & 22 & 31.4 \\
\hline Fairly well & 53 & 50.0 & 77 & 38.1 & 14 & 20.0 \\
\hline Very well & 8 & 7.5 & 12 & 5.9 & - & - \\
\hline
\end{tabular}

of this new domain. Yet it is surprising that such a small number of schools state that they are very well acquainted with ICL, while in all three subsamples the categories "not". "a little" and "moderately" have high scores. An explanation of this phenomenon might be that the active schools in the sample were active on their own initiative ("grassroot developments"). while ICL as a new domain was announced in the December 1982 white paper of the government. Only after this announcement did institutions like the National Foundation for Curriculum Development, teacher training colleges and others start their activities directed at operationalization and dissemination of what became conceived of as ICL. This process was not crystallized fully in the Spring 1984. From our data we can also conclude that the schools are using a combination of sources to get informed about ICL, but the three subsamples do not differ in this respect.

Our conclusion is that clarity about goals and content of the innovation, mentioned by Fullan [3] as one of the factors influencing implementation, was present only in a limited fashion in Dutch schools. 


\section{Inservice training and staff development}

Ongoing inservice and staff development is mentioned by Fullan $[3,4]$ as one of the important factors affecting the implementation of change. From Table 6 it is clear that the schools also consider the possibility of inservice courses an important factor. However, some marginal notes have to be made. Table 9 contains an overview of topics which, according to teachers should be dealt with in inservice courses. From this table it can be concluded that the teachers consider it important that the inservice training in ICL is narrowly linked up with the daily problems they encounter in their teaching practice. They have a real desire for concrete materials and ideas for the lessons and for a training on a concrete level. This opinion is opposite to that of the teacher trainers who are conducting the inservice training.

Table 9. Topics to be dealt with in inservice courses according to the teachers (the percentage of teachers who judged the topics as important is show $\mathrm{n}$ for each topic)

\begin{tabular}{|c|c|c|}
\hline $\begin{array}{l}\text { Topics (in order } \\
\text { of importance) }\end{array}$ & Schools active on student level $(N=107)$ & Schools in orientation phase $(. Y=202)$ \\
\hline First topic & $\begin{array}{l}87 \% \text { obtaining ideas for lessons and organisation } \\
\text { forms for their own teaching }\end{array}$ & $\begin{array}{l}91 \% \text { : obtaining ideas for lessons and organisation forms for } \\
\text { their own teaching }\end{array}$ \\
\hline Second topic & $\begin{array}{l}57 \% \text { : getting acquainted with specific computer } \\
\text { applications }\end{array}$ & $80 \%$ : learning to handle the equipment \\
\hline Third topic & $\begin{array}{l}53 \% \text { : orientation on the societal aspects of } \\
\text { computer applications }\end{array}$ & $68 \%$ : general orientation on computers and computer science \\
\hline Fourth topic & $\begin{array}{l}51 \% \text { : general orientation on computers and } \\
\text { computer science }\end{array}$ & $65 \%$ orientation on the goals of ICL \\
\hline Fifth topic & $50 \%$ : learning to program & $64 \%$ : orientation on societal aspects of computer applications \\
\hline Sixth topic & $48 \%$ : learning to handle equipment & $54 \%$ : getting acquainted with specific computer applications \\
\hline Seventh topic & $48 \%$ : orientation on the goals of ICL & $44 \%$ : learning to program \\
\hline
\end{tabular}

In another study [5] teachers and teacher-trainers were asked to express their preference with respect to two extreme formats of inservice courses of ICL. These two extremes can be characterized as follows:

\section{Format I}

Course directed at mastery of information technology as a knowledge domain

Transfer of knowledge on teacher's level

No treatment of concrete lesson materials

No didactical hints

\section{Format II}

Course closely directed at designing lessons in the introduction to information technology

Transfer of knowledge on pupil's level

Treatment of concrete lesson materials

Didactical hints included

Where format II is refers to a treatment of the subject matter on a very concrete level ("pupil level"), format I is aimed at transfer of disciplinary knowledge on the basis of which teachers must be able to design lessons themselves.

A group of teachers (of which a part had attended or were attending inservice courses) was asked to state which format indicated the greatest need and 15 teacher trainers were asked to indicate which format they were using for their inservice courses (see Table 10).

$\begin{aligned} & \text { Table 10. Most desired format for teacher inservice training according to teachers } \\
& \text { vs the format foilowed by teacher-trainers (absolute and percentage) }\end{aligned}$
\begin{tabular}{lcccc} 
& \multicolumn{3}{c}{ Teacher-trainers } \\
& Teachers $(N=956)$ & \multicolumn{2}{c}{$(N=15)$} \\
Most desired format & ABS & $\%$ & ABS & $\%$ \\
\hline Only format I & 33 & 3.5 & 3 & 20 \\
More of format I than format II & 136 & 14.2 & 9 & 60 \\
Equal attention to both & 291 & 30.4 & 2 & 13 \\
More of format II than format I & 410 & 42.9 & 1 & 7 \\
Only format II & 73 & 7.6 & - & - \\
No opinion & 13 & 1.4 & - & - \\
\hline
\end{tabular}

From the results it is clear that the preference of teachers for format II does not fit with the view of the teacher trainers. Teachers would like to have inservice training on a concrete and specific level, close to their daily classroom practice. Teacher trainers, on the contrary are striving for 
courses in which the teachers will be introduced to information science and computer science, so that starting from a basic level of conceptualization of the new domain, teachers will not only be able to design their lessons, but also to follow the rapid developments in the domain. We think that the desires of the teachers are understandable: without having extra time they are expected to be able to teach ICL. But at the same time, we think that one should not create a vision on the new domain by just giving inservice training which is restricted to these "short run" objectives on the pupils' level. Fullan [3] warns that the use of training can be grossly misapplied unless it is understood in relation to the meaning of change and the change process taken as a whole ( $p$. 66). It is therefore important that, if desired, after the first wave of inservice courses more teachers like format I, inservice courses should be directed toward the development of new concepts, skills and behavior on the side of the teachers.

\section{Teaching-learning materials}

Teaching-learning materials consist not just of written materials, but may include educational software and audiovisual resources. Important aspects of curricular materials, which are in effect implementation, are quantity, quality and usefulness of teaching-learning packages as a whole. Good materials provide the teacher with a vehicle to understand the innovation and to be able to use it without further instruction. From Table 6 we see that ICL teachers consider the availability of sufficient tedching-learning materials (including software) one of the most important factors for a successful implementation.

Of the 107 schools which are teaching ICL to their pupils, 57 schools (53\%) are using commercially available materials, while 28 schools $(26 \%)$ are working with materials developed by colleagues from other schools. Teachers are spending much time in developing their own materials, e.g. teachers in general secondary schools spend an average of $80 \mathrm{~min}$ a week. If one combines this time investment with the time teachers have to invest in inservice courses, in keeping up with the new developments and in the actual preparation of their lessons, it is not surprising that they emphasize the importance of the availability of sufficient usable materials.

\section{Participation in other innovations}

Fullan [3, p. 63] lists the history of innovative attempts as another factor affecting the implementation of an innovation. The more the teachers or others have had negative experiences with previous implementation attempts in the district or elsewhere, the more cynical or apathetic they will be about the next change presented regardless of the merit of the new idea or program (p. 63).

The schools in the sample were asked about their experiences with other innovations. Schools who participated in other projects were more inclined to apply for participation in an experiment with ICL launched by the government, than schools with little or no experience. Schools were generally favorable about their experiences in earlier innovative projects, so that we cannot test the proposition put forward by Fullan. Apparently, certain schools are more apt to participate in innovations than other schools, independent of the topic and the kind of the innovation.

\section{CONCLUDING REMARKS}

The main aim of the survey study was to perform a context analysis to provide policy makers, innovation planners, teacher trainers and curriculum developers with information about the state-of-the-art about information and computer literacy (ICL) in the schools, before a new governmental policy directed at introducing some form of basic education in ICL should be put into practice. The data collected in a sample of Dutch junior secondary schools are not data about a carefully planned implementation, but in fact reflect a picture of the grassroots developments which were going on in the Netherlands in the course year 1983/1984.

We consider the introduction of computers in education in general and therefore also the introduction of ICL as a new domain as an innovation which has to be implemented in the schools. For the construction of the instruments used in the study, we therefore took as an underlying theoretical framework some of the factors, which Fullan [3] mentions as affecting the implementation of innovations. In this paper we discuss how far schools, who are in fact experimenting 
with ICL on their own initiative, are scoring on some of these factors. As this analysis was not the main objective of the study, we have to interpret the results with some reservations. This analysis is just the first step in analyzing whether these factors play a role in this innovation.

After the discussion of the results in the preceding section, we must conclude that the influence of the factors studied is highly dependent on the specific situation of an individual school. As there is no strategy planned beforehand by the government, the ways schools are starting with this innovation vary tremendously. Very little can be said about a priority or an ordering in the factors. At best one can conclude that the school needs to have to its disposal certain material facilities, like hardware and teaching-learning materials, and that teachers and administrators need to have a positive attitude towards information and computer literacy. This positive attitude is selfevidently found in the schools which are the fore runners; material and immaterial support (see Table 6) seem to be necessary conditions for generating this in the main stream of the schools. The other factors are arranged in such a way that it is difficult to distinguish a hierarchy among them.

A tentative conclusion from our study [2] and from the implementation literature, esp. Fullan $[3,4]$ will be presented here. The following scheme is an attempt to bring some structure in the factors investigated in this study. Our conclusion has to be considered as a working hypothesis. within which the results of our study fit.

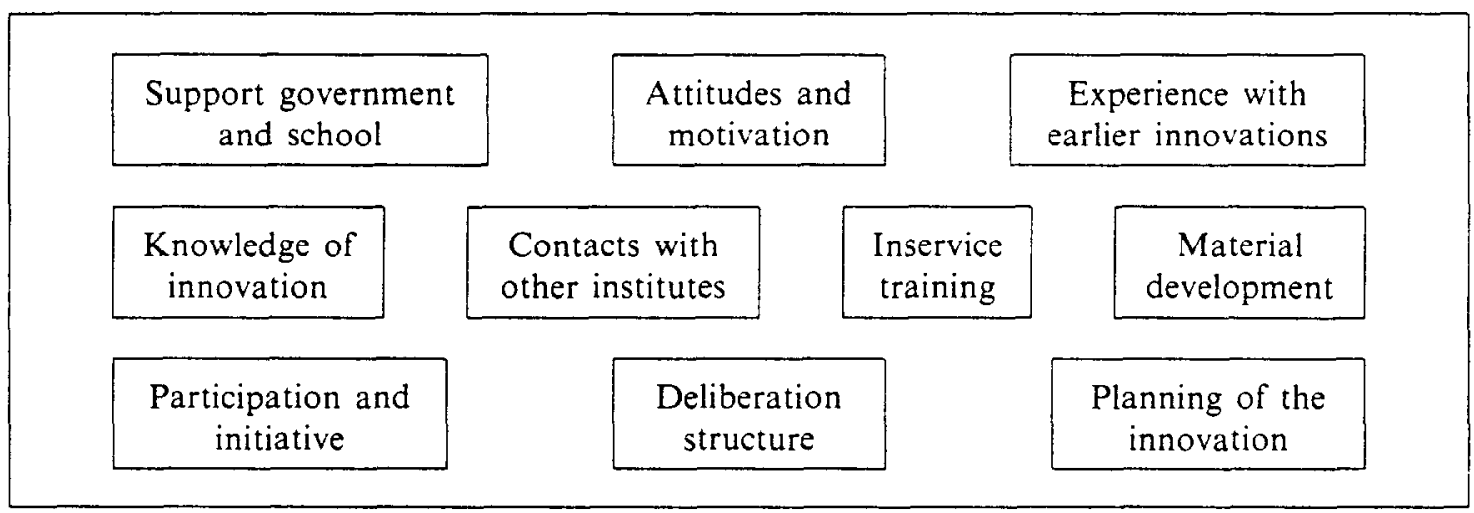

The factors in the upper part can be considered as necessary, but not as sufficient factors. Support from the government and the school administrators are of great influence. Add to this a positive attitude and motivation of those involved and positive experiences with earlier innovations, then the innovation will not be rejected beforehand and a context is present in which it can get a real chance.

The factors in the middle block are of special importance at the beginning of the implementation. They will be effective in combination. One or more of these factors will usually be the motive for a school to initiate activities with ICL, which will lead to taking up the others.

The lower block of three factors are of relevance after the first exploration of the innovation, i.e. during the continuation of the implementation and in the beginning of the incorporation phase.

This tentative conclusion may serve as a recommendation for a policy strategy. Such a strategy should focus in the beginning in any case on the factors in the middle block and especially on the teachers. The government and the school administration must offer facilities so that individual teachers will have time and real possibilities for getting acquainted with and becoming competent in the innovation, and have proper materials (hardware and software) at their disposal. There is a need, especially in the beginning phase, for concrete exemplary teaching materials. Later, teachers are expected to be more receptive to background information and a broader perspective of the innovation.

\section{REFERENCES}

1. Plomp Tj. and van de Wolde J. The new information technologies in education: lessons learned and trends observed. Eur. J. Educ. 20, 243-256 (1985).

2. Valkenburg H. D. and Carleer G. J. Beschrijiing en analyse van uitkomsten van landelijk onderzoek burgerinformatica. Twente University of Technology, Department of Education (1985). 
3. Fullan M. The Meaning of Educational Change. Teachers College Press. Columbia University. New York (1982).

4. Fullan M. (1985) Curriculum implementation. In The International Encyclopedia of Education (Edited by Husen T. and Postlethwaite N.). pp. 1208-1215. Pergamon Press, Oxford (1985).

5. Carleer G. J. and Woelinga D. H. Informatica-nascholing: een intentarisatie van vraag en aanbod. Twente University of Technology, Department of Education (1985). 